\title{
Central Colorado Assessment Project-Application of Integrated Geologic, Geochemical, Biologic, and Mineral Resource Studies
}

\author{
By T.L. Klein, S.E. Church, J.S. Caine, T.S. Schmidt, and E.H. DeWitt
}

\section{Introduction}

Central Colorado is one of the fastest-growing regions in the Western United States. Population along the Front Range increased more than 30 percent between 1990 and 2000 (http://www.demographia. com/db-metro3newworld.htm) with some counties within the study area such as Park County experiencing greater than 100 percent growth (http:// www.censusscope.org/us/s8/rank_popl_growth.html). This growth has caused tremendous demand for natural resources and has created challenging landmanagement issues related to the interface between wilderness and urban expansion. Management of this wilderness/urban interface will benefit from current digital geoscience information collected by the U.S. Geological Survey (USGS) Central Colorado Assessment Project that began in 2003. Approximately 20,800 square miles $\left(53,800 \mathrm{~km}^{2}\right)$ of land divided almost equally between the public and private sectors were part of the assessment (fig. 1).

The study area includes much of the Colorado Mineral Belt, a northeast-trending zone that contains 30 economically significant metal deposits. Historically, the area provided much of Colorado's metal production. The only active gold and molybdenum mines in Colorado lie within the study area. Recently, metal and uranium exploration activity has increased sharply in response to record prices for metals and uranium. This further underscores the need for up-to-date geoscience information presented in compatible GIS databases in order to facilitate rapid land-management decisions.

Cooperative studies by USDA Forest Service, National Park Service supported by the USGS Mineral Resources (MRP), and National Cooperative Geologic Mapping Programs (NCGMP) contributed to the mineral-resource assessment and included regional geologic mapping at the scale 1:100,000, collection and geochemical studies of stream sediments, surface water, and bedrock samples, macroinvertebrate and biofilm studies in the riparian environment, remote-sensing studies and geochronology. Geoscience information available as GIS layers has improved understanding of the distribution of metallic, industrial, and aggregate resources, location of areas that have potential for their discovery or development, helped to understand the relationship of tectonics, magmatism, and paleohydrology to the genesis of the metal deposits in the region, and provided insight on

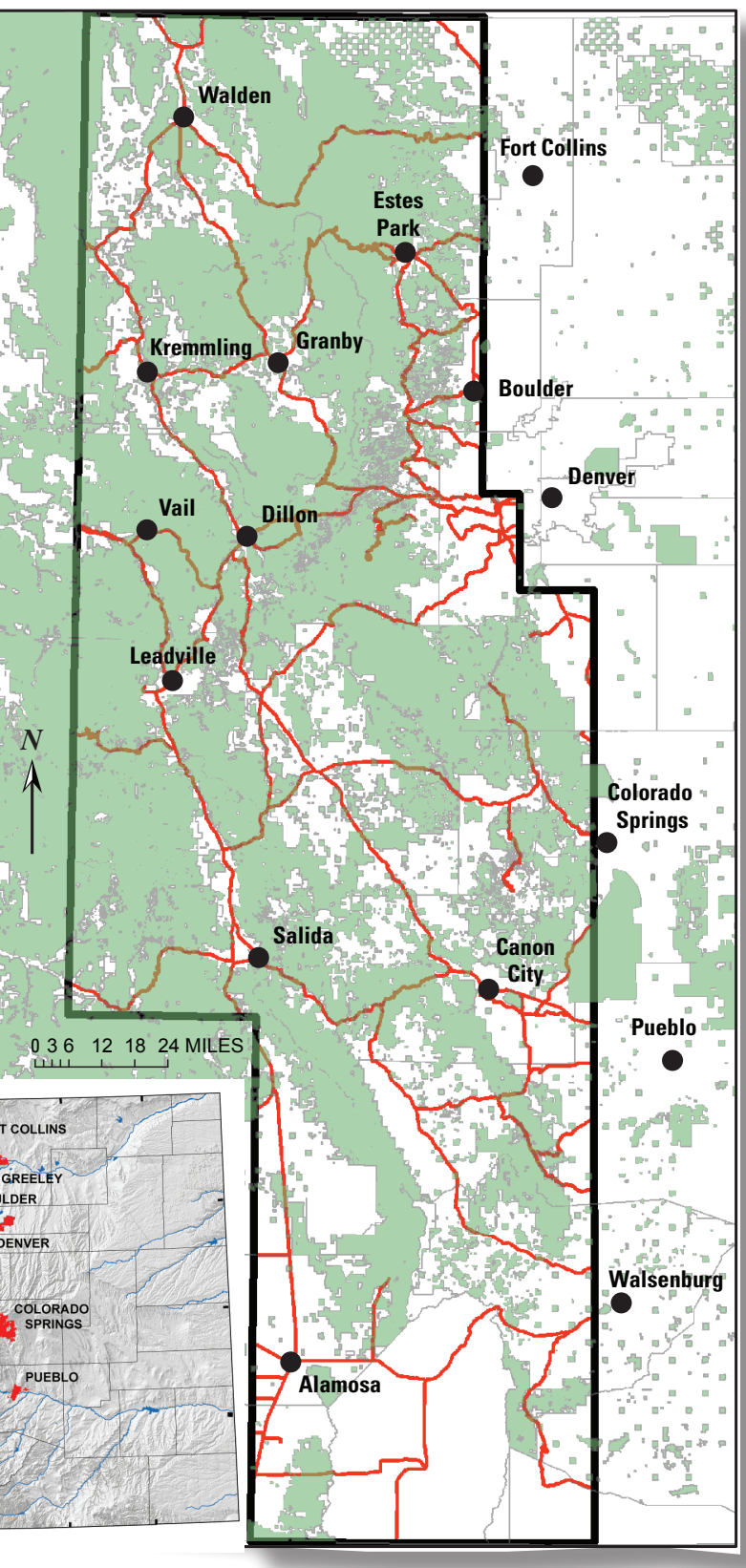

Figure 1. Location of Central Colorado Assessment Project study area. The thick black line in the larger figure is the outline of the study area. Red lines are major highways. Blue shading is water. White fill represents private lands and green fill represents public lands, managed mainly by the U.S. Department of Agriculture Forest Service, the National Park Service, and the Bureau of Land Management. 
the geochemical and environmental effects that historical mining activity and natural, mineralized rock exposures have on surface water, ground water, and aquatic life.

\section{Geologic Mapping}

One of the primary objectives of the CCAP is preparation of a regional geologic map $(1: 100,000)$ from previously published maps and new mapping by the USGS and the Colorado Geological Survey. The need for this new compilation is illustrated in figure 2 where a small part of the new map is compared with the same area of the only regional digital geologic map (Tweto, 1979) available before this study. This new geologic map provides the underlying geologic framework for environmental, mineral-deposit, tectonic, geochemical, geochronology, remote-sensing, and geophysical studies.

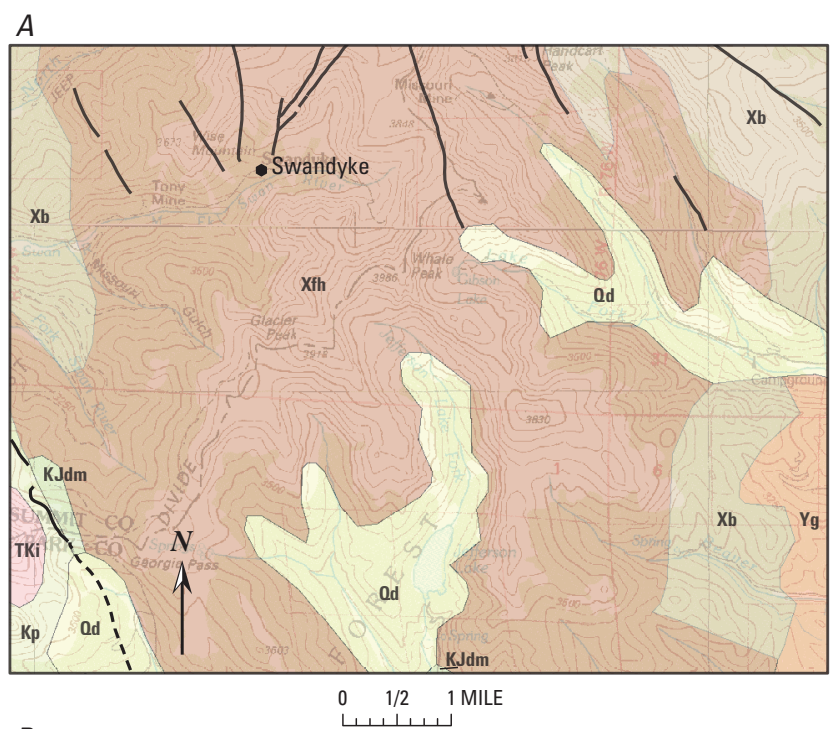

$B$

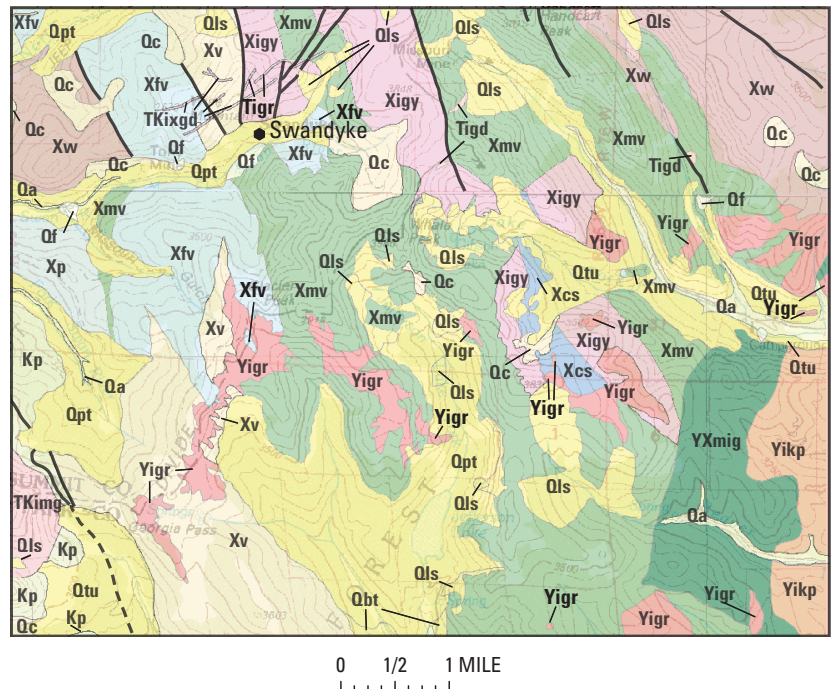

Figure 2. Geologic map of the Swandyke area in the western part of the Colorado Front Range. Map $A$ (Tweto, 1979) was published at a 1:500,000 scale and was the only regional geologic map available as a GIS product. Map $B$ is the same area from the regional geologic map compiled at a 1:100,000 scale for the Central Colorado Assessment Project. Note the differences in detail and the number of rock units.

\section{Colorado Mineral Belt Studies}

Metal mining in Colorado began in 1858 and was instrumental in the early economic development of the State. Gold, silver, lead, and later, tungsten and molybdenum were produced from eight general types of hydrothermal deposits identified in figure 3. With the exception of the large gold deposit at Cripple Creek, nearly all the deposits in the CCAP study area occur within the Colorado Mineral Belt. Compilations of published geochronology, igneous-rock geochemistry, and lead isotope data, and additional data from new samples have been used to understand the geochemical and temporal relationships of magmatism to metalliferous hydrothermal systems in the area. These studies have been integrated with the structural studies summarized below to develop a regional model for the formation of metal deposits in the northeastern part of the Colorado Mineral Belt.

\section{Structural Studies and Controls of Mineralization}

New research for the CCAP in the central Colorado Front Range has resulted in alternative interpretations that indicate that tectonic

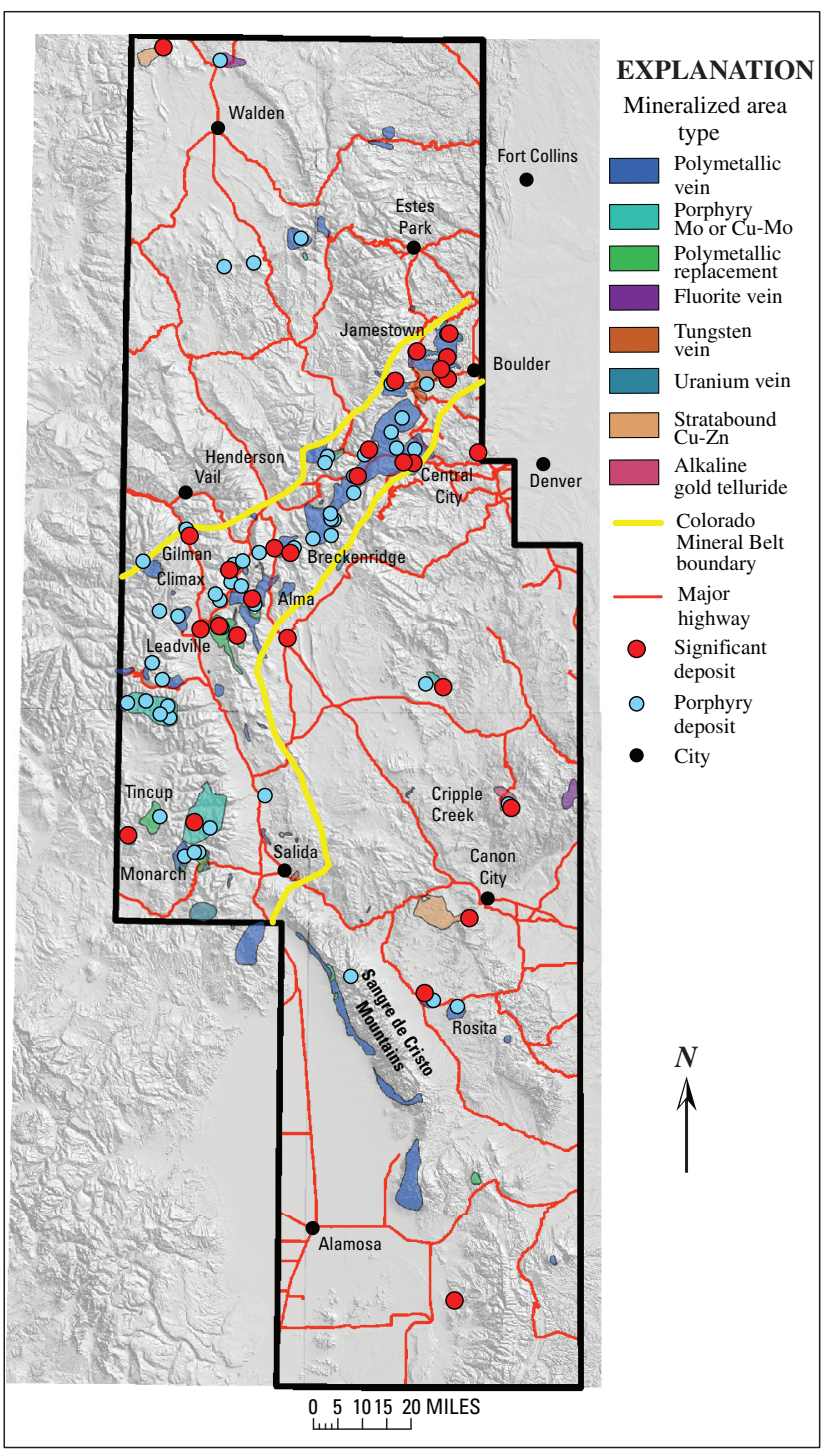

Figure 3. Relationship of the Colorado Mineral Belt to porphyry molybdenum (Mo) and copper-molybdenum (Cu-Mo) deposits and significant deposits. Mineralized areas are classified by dominant hydrothermal mineral deposit type. Significant deposits are those with contained metal in the upper 10 percent of their deposit type worldwide. 
processes in the Early Tertiary combine to form shallow, polymetallic vein (PMV) deposits, the most common type of deposits in the study area. These deposits in the northeastern part of the Colorado Mineral Belt were the first to be discovered in Colorado and combined to produce more than $\$ 850,000,000$ (in 2007 dollars) of base and precious metals by 1970 (Lovering and Goddard, 1950; United States Bureau of Mines Yearbooks 1947 through 1970).

The fundamental ingredients needed to make PMV deposits include heat, fluids, metallic ions, and permeability. Our new research focused on permeability, which can be generated in several ways. Previous studies in the area suggest that PMV deposits commonly form along preexisting geologic structures such as shear zones where the host rocks are "weak" and susceptible to fracturing. This in turn makes them permeable pathways for magmas and associated metal-rich fluids to ascend through the crust to a depositional site. Although this can be true, not all shear zones are the same-some are permeable and others are not. Some shear zones are "strong" when tectonic forces are applied to them, making them resistant to fracturing and thus impermeable.

One example of a crustal weakness thought to have controlled the location of one of Colorado's most productive regions of PMV deposits is the Precambrian Idaho Springs-Ralston Shear Zone (ISRZ). However, the analysis of compiled structural and mineral-deposit data from existing reports and new data collected from outcrop studies results in several key observations shown in figure 4. (1) Locations of mineral-deposit-related structures do not correlate well with plutons, the ISRZ, or other major brittle faults or fracture zones. (2) Mapped structures suggest that myriad directions of potential permeability existed. Thus metalliferous, hydrothermal fluids were free to flow in many directions at any time during the formation of the metal deposits if stress was isotropic. (3) The PMV deposits show either preferential east-northeast trends that are well correlated with Laramide orogeny stress directions or radial trends proximal to Late Cretaceous and Tertiary igneous intrusions and show a weak correlation with structures related to the ISRZ. (4) Minor differences in orientation and intensity of potential structures existed that may have controlled permeability within the ISRZ compared with similar structures outside the ISRZ.

Our observations suggest that the ISRZ did not host the ascent of metal-rich magmas or associated fluids and did not act as the primary control of mineral-deposit locations in the Colorado Front Range. Rather, responsible processes likely include (1) proximity to epizonal plutons; (2) competition between varying magnitudes and orientations of shallow regional tectonic stresses, overburden stresses, and local stress perturbations related to pluton emplacement; and (3) the formation of "self-generated" permeability from magmatic heat-generated pressure leading to in-situ fracturing within the various stress fields. Our work concludes that all of the processes listed above worked together. Thus, tectonic-stress fields, depth range of magma formation, and the age, location, and style of potential permeability structures should all be considered when determining the potential for undiscovered PMV deposits.

\section{Impact of Bedrock Composition, Mineral Deposits, and Historical Mining on Water, Sediment, and Biology in the Riparian Environment}

As part of the CCAP, we conducted an assessment of 198 watersheds in an area of approximately $54,000 \mathrm{~km}^{2}$. Water, sediment, and aquatic insects were collected from watersheds underlain by single lithogeochemical units or from watersheds that contained the hydrothermally altered rock. Historical mining for base and precious metals was extensive in the Colorado Mineral Belt, which has elevated concentrations of base metals (primarily cadmium, copper, lead, and zinc) in water and sediment.

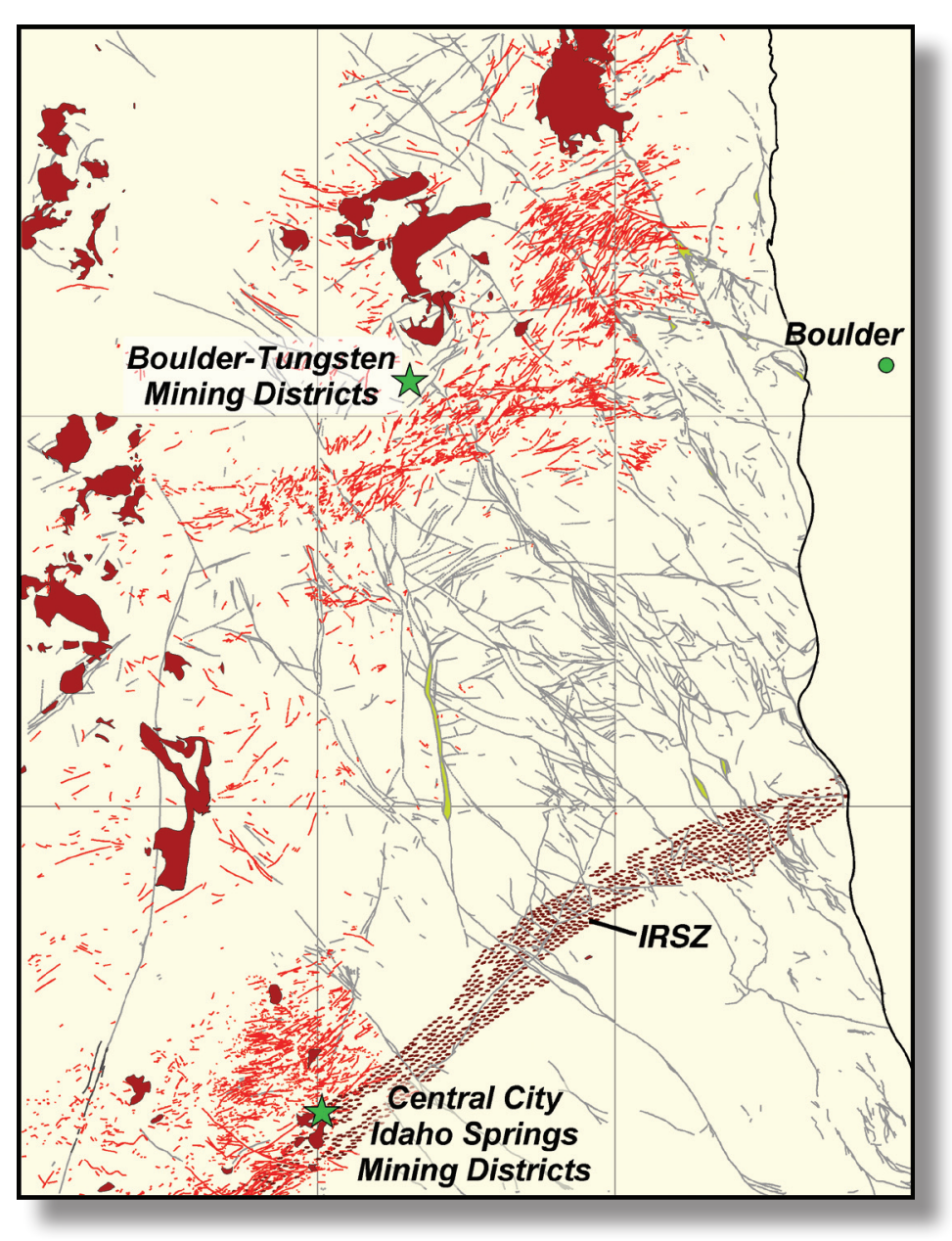

Figure 4. Potential permeable structures of the Colorado Front Range and Cretaceous and Tertiary plutons (red areas). Also shown are the Idaho Springs-Ralston Shear Zone (IRSZ) as irregular thick brown lines, brittle faults as thick gray lines with yellow fill indicating zones of extensive hydrothermal alteration, and polymetallic veins (PMV) as bright red lines. Note that the PMV cut all major brittle faults, the Cretaceous and Tertiary plutons are only coincident with the IRSZ in one location, and only a small proportion of the PMV is coincident with the ductile IRSZ.

We tested the assumption in the study area that degraded water and sediment quality are restricted to watersheds in which historical mining occurred and found the four most important parameters that control elevated trace-metal concentrations in water and sediment are lithology, hydrothermal alteration, the type of contained mineral deposits, and presence of historical mining. Base-metal concentrations among unaltered rock types showed small geochemical variations that reflect host lithology. Base-metal concentrations in sediment from watersheds underlain by hydrothermally altered rock are elevated. Classification of watersheds (mined and unmined) on the basis of the type of contained mineral deposit (fig. 5) discriminates watersheds that have degraded water and sediment quality better than the other parameters. Only about 5 percent of the watersheds in the study area have been affected by historical mining, whereas hydrothermally altered rocks underlie a much larger part of the study area and have weathered to produce water and sediment that have naturally elevated geochemical baselines.

Ecological risk assessments rarely use models of the natural distribution of metals in the earth. To develop ecologically relevant baselines for environmental assessments, we sampled aquatic communities from 159 streams underlain by single lithogeochemical units (fig. 6) and characterized the extent of mining-related disturbance, hydrothermal alteration, and deposit type found within each watershed. 


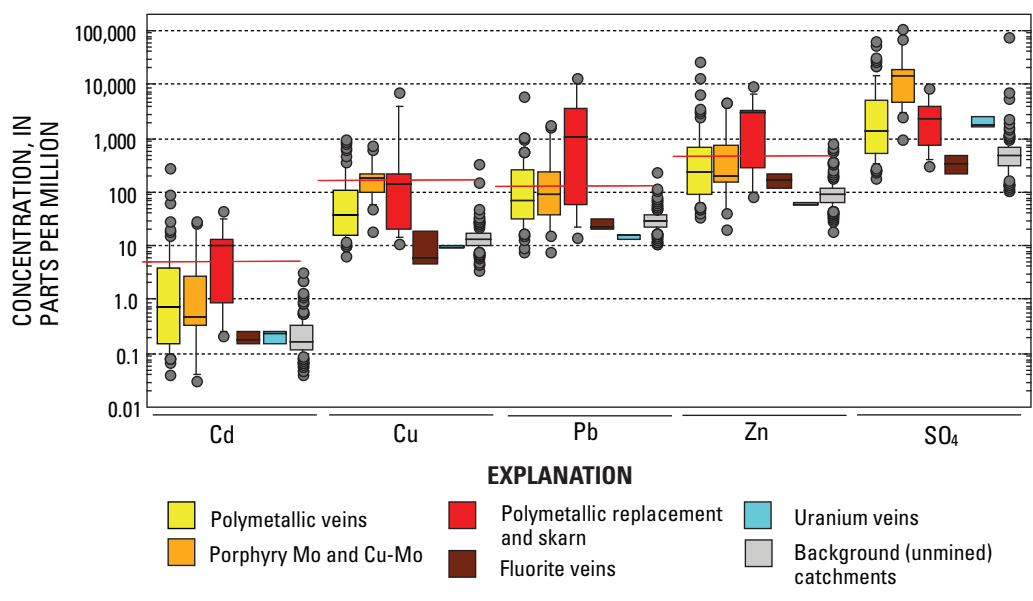

Figure 5. Concentration data in sediment from watersheds classified by mineral-deposit type. ( $\mathrm{Cd}$, cadmium; $\mathrm{Cu}$, copper; $\mathrm{Pb}$, lead; $\mathrm{Zn}$, zinc; $\mathrm{SO}_{4^{\prime}}$ sulfate).

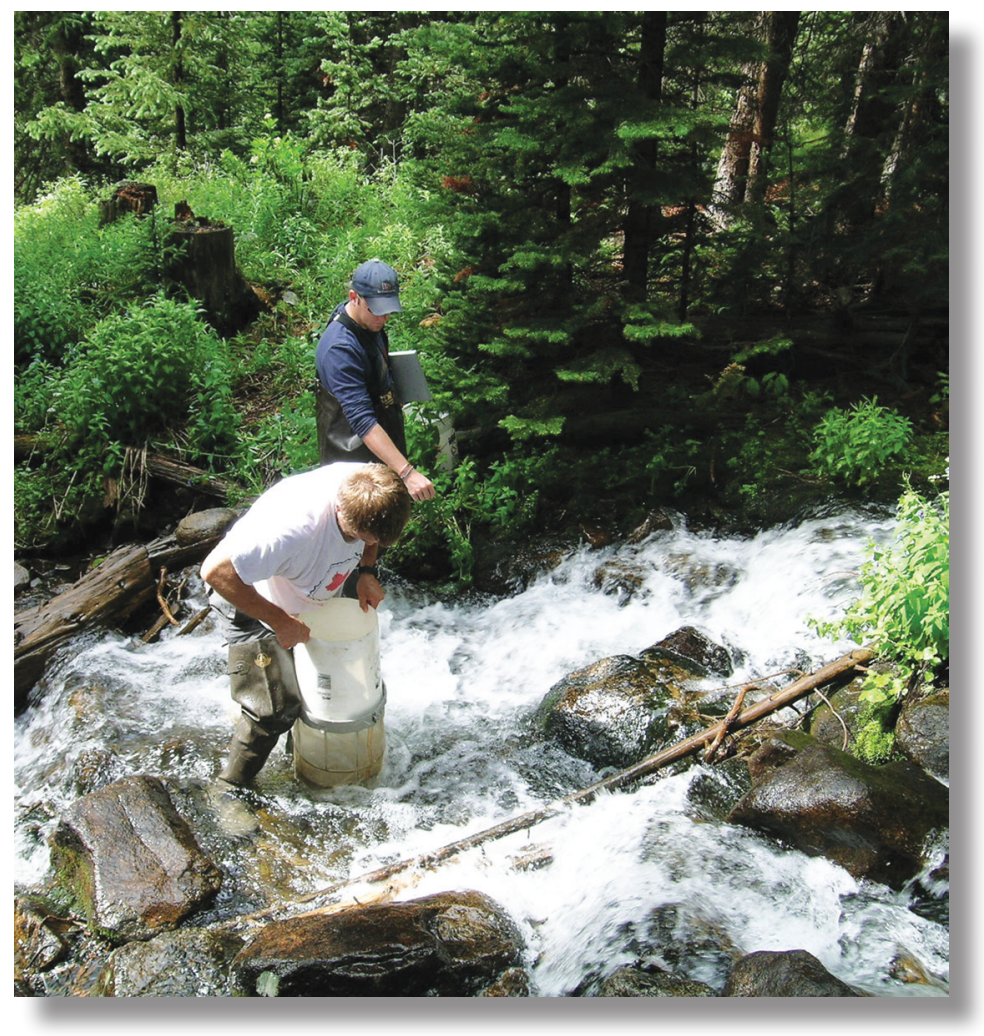

Figure 6. U.S. Geological Survey field party sampling aquatic invertebrates in central Colorado.

Results show that the number of different types of aquatic insects (richness) and the density of metal-sensitive insects are negatively affected by mining within a watershed (fig. 7). However, the large and overlapping statistical ranges in these parameters make it difficult to use them to differentiate between mined and unmined watersheds.

The type of hydrothermal alteration also influences aquatic communities. Propylitic mineral alteration can cause higher concentrations of metals in water and sediment in both mined and unmined watersheds, but in some cases these metals are not biologically available due to minerals found in the deposit that ameliorate metal toxicity. In phyllic-mineral-altered watersheds, pyritebearing minerals release metals and acids into the stream, reducing the number of different types of insects and the number of metal-sensitive insects found per square meter of streambed. Different deposit types also influence aquatic-community responses to the effects of mining.
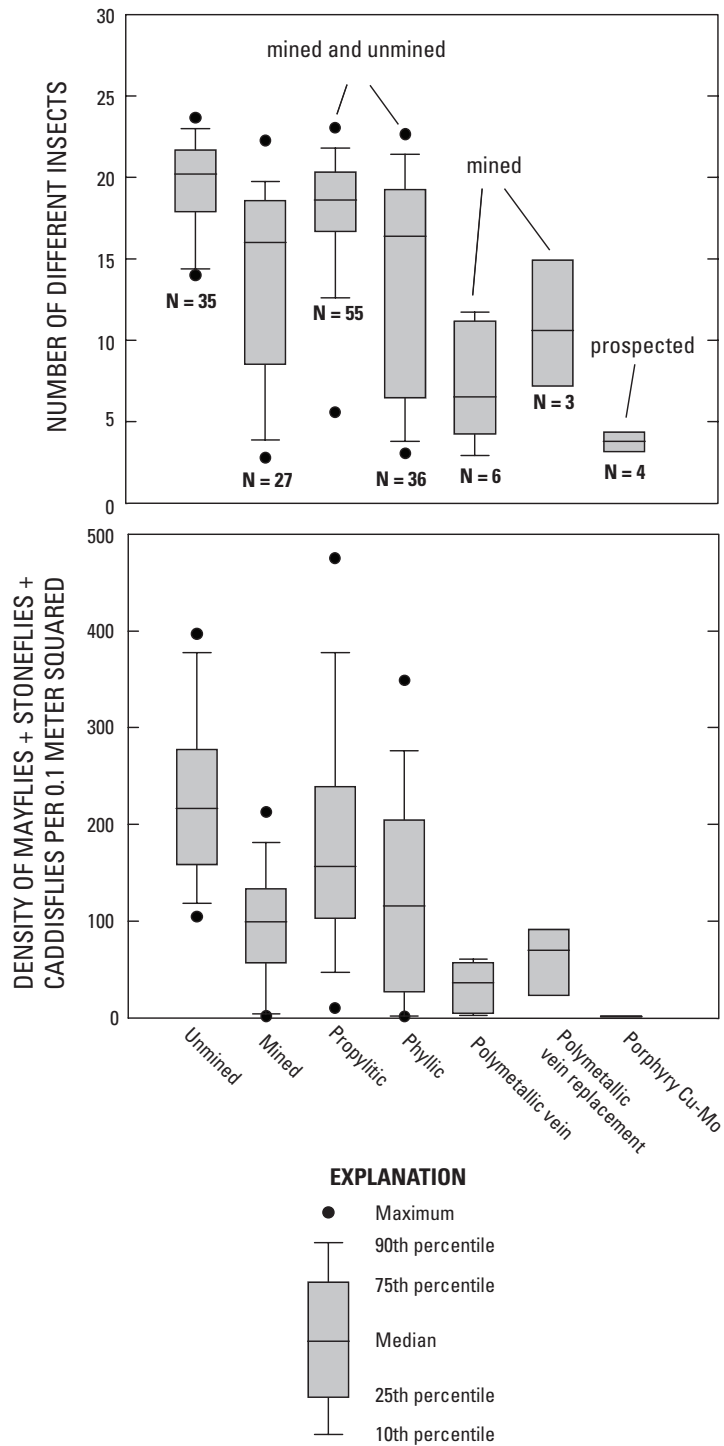

Figure 7. Box plots illustrating the number of different types of aquatic insects (richness) and the density of metal-sensitive insects in sampled catchments by alteration and metal deposit type. Propylitic and phyllic classes are both mined and unmined. Polymetallic vein and polymetallic vein replacement classes are mined only. Porphyry Cu-Mo class is prospected. (Cu, copper; Mo, molybdenum).

These results show that integrative science linking geoscience and ecological data improved our ability to predict the ecological risks associated with mining specific rock and deposit types. Future ecologically relevant assessments of the effects of geology on the environment should include the assessment of hydrothermal alteration, deposit type, and the extent of mining disturbance within watersheds underlain by single lithogeochemical units.

\section{References Cited}

Lovering, T.S., and Goddard, E.N., 1950, Geology and ore deposits of the Front Range Colorado: U.S. Geological Survey Professional Paper 223, $319 \mathrm{p}$.

Tweto, O.L., 1979, Geologic map of Colorado: U.S. Geological Survey Special Map, 1:500,000.

United States Bureau of Mines, 1947-1970, Minerals Yearbook: United States Bureau of Mines. 